\title{
HERNE JA VIRNA LYPSYLEHMIEN REHUNA
}

\author{
IRJA UOTILA \\ Kotieläinhoidon tutkimuslaitos, Tikkurila
}

Saapunut 31. 12. 1958

Herneen ja virnan viljely on maassamme ollut verrattain vähäistä, ollen niiden yhteinen ala viljelysalasta alle 2 prosentin. Hernettä ja virnaa on viljelty paitsi puhdaskasvustona myös seoksena, useimmiten kauran kanssa. Palkokasvien puhdaskasvustoina viljelyn haitallisena tekijänä on ollut niiden lakoutuminen, joka aiheuttaa häiriytymistä kasvussa sekä alttiutta mätänemiselle. Viime vuosina onkin alettu maassamme kiinnittää erityistä huomiota niiden viljelyyn seoksina (vrt. 14, 1, 9, 15, 7). Sekakasvustoissa heinäkasvit pysyvät antamaan tukea palkokasville. Onpa todettu, että seosviljelyksessä tuleentuminen tapahtuu nopeammin, joten se tekee mahdolliseksi herneen ja virnan viljelyn satoja kilometrejä niiden nykyisiä viljelyrajoja pohjoisempana. Seosviljoista saadaan huomattavasti runsaampia valkuaissatoja hehtaarilta kuin kauran puhdasviljelysta (7).

Herneen ja virnan etuina rehukasveina on pidettävä niiden korkeata valkuaispitoisuutta. Nykyisistä maassamme viljellyistä rehukasveista niissä on korkein valkuaispitoisuus. Kotoisiin rehuihin perustuvan lypsylehmien ruokinnan järjestelyssä on suurimpana vaikeutena juuri riittävän valkuaispitoisuuden saaminen muussa suhteessa normit täyttävään ruokintaan. Puna-apilan viljely on maassamme tärkein valkuaistuotannon perusta ja sen kasvuedellytysten parantamisella ja viljelyn lisäämisellä voidaan saavuttaa hyviä tuloksia valkuaisomavaraisuuden lisäämisessä. Apilanviljelyn haittana on ainakin toistaiseksi kuitenkin maassamme muutamia pahoja esteitä, kuten esim. viljelysmaitten liika happamuus, talvenkestävien apilakantojen puute ja talvituhosienet. Samoin epäedulliset sää ym. olosuhteet ovat vaikeuttaneet sen siemenviljelyä.

Karjatalouden tuotannon turvaamiseksi on maassamme turvauduttu runsaaseen öljyväkirehujen tuontiin ulkomailta. Kotieläinhoidon tutkimuslaitoksella on suoritettu herneellä ja virnalla maidontuotantokoe, jonka tarkoituksena oli selvittää näiden rehujen soveltuvuutta lypsykarjan rehuksi, sekä sitä missä määrin näiden rehujen avulla voidaan korvata öljyväkirehut ja silti saavuttaa rehuannoksen riittävä valkuaispitoisuus. Myöskin suoritettiin sulavuuskokeet pässeillä kummallakin koerehulla. 
Ulkomaisista ruokintakokeista mainittakoon Hasssosin v. $1910-1913(5,6)$ suorittamat kokeet, joissa hän käytti hernettä tai virnaa $2 \mathrm{~kg} / \mathrm{p}$ eläintä kohti korvaamaan saman painomäärän seosta, jossa oli $40-50 \%$ maapähkinäkakkua ja $50-60 \%$ vehnänlesettä. Maitomäärä aleni keskimäärin $0.14 \mathrm{~kg} / \mathrm{p}$ eläintä kohti, kun taas elopaino lisääntyi keskimäärin $2 \mathrm{~kg}$. Hän laskee $1 \mathrm{~kg}$ hernettä tai virnaa vastaavan 1 ry:ä. HANSSON katsoo, että ainakin $50 \%$ öljyväkirehuista voidaan korvata herneellä tai virnalla. RoSENGREN (13) ei tutkimuksissaan voinut havaita herneellä tai virnalla (2 tai $4 \mathrm{~kg} / \mathrm{p}$ eläintä kohti) olevan mitään haitallista vaikutusta maidon makuun tai hajuun eikä voin laatuun.

\section{Tutkimusmenetelmät}

Ruokintakoe suoritettiin lypsylehmillä Maatalouden tutkimuskeskuksen Ayrshirekarjassa vuosina $1957-1958$. Kummallakin tutkittavalla rehulla suoritettiin jaksokoe saman aikaisesti, joten niiden välinen vertailu oli mahdollista. Ryhmiin kuului 6 lehmää. Jaksojen pituus oli 30 päivää ja niiden välillä olivat 5 päivän pituiset siirtokaudet. Ennen koetta oli 10 päivää kestävä tasoituskausi.

Herne oli vihreää Kalle-hernetta, joka laadultaan täytti ruokaherneelle kaupassa asetetut vaatimukset. Virna oli pienisiemenistä ulkomaista lajiketta. Kumpikin käytettiin hienoksi jauhettuna.

Rehut ja maidot punnittiin joka päivä, ja rasvamääritys suoritettiin joka viides päivä kahden peräkkäisen päivän suhteellisesti otetusta yhteisnäytteestä. Rehunäytteitä kerättiin 10 päivän pituisilta jaksoilta ja suoritettiin rehuanalyysi. Elopaino punnittiin jokaisen jakson lopussa.

Sulavuuskokeet suoritettiin pässeillä, kummallakin koerehulla suoritettiin koe kahdella eläimellä. Kymmenen päivän koekautta edelsi samanpituinen valmistuskausi, jona aikana ruokinta oli sama kuin koekaudella.

\section{Maidontuotantokoe}

Kokeessa käytettyjen ryhmien kokoonpano ilmenee taulukosta 1. Ryhmä I sai koekautena virnoja, ryhmä II herneitä. Täysin tasalaatuisten ryhmien muodostaminen ei ole mahdollista Maatalouden tutkimuskeskuksen karjassa, joka on aivan liian pieni (n. 40 lypsylehmää) ruokintakokeiden järjestämiseen. Ryhmien keskiiän eroavuus johtui suureksi osaksi ryhmän I yhdestä lehmästä, joka oli huomattavasti muita vanhempi $(11.3 \mathrm{v})$. Yksityisten lehmien tuotoksesta on mainittava, että se vaihteli esikaudella n. $10-30 \mathrm{~kg} / \mathrm{p}$, kuitenkin kumpaankin ryhmään oli valittu eri tuotostasoja edustavia lehmiä. Kokeessa käytettyjen rehujen kemiallinen koostumus on esitetty taulukossa 2. Ruokinnassa käytettiin normeina PoiJÄRVEN (11) esittämiä. Jokaisen jakson rehuannoksen ry-, sulavaraakavalkuais- ja kuiva-ainemäärät laskettiin jakson aikana kerättyjen näytteiden pitoisuuksien keskiarvoa käyttäen. Koejakson aikana käytetyt virnamäärät olivat $2.2-3.7 \mathrm{~kg} / \mathrm{p}$ 
Taulukko 1. Ryhmitystietoja.

Table 1. Data concerning the test groups.

Ryhmä I Ryhmä II

Group I Group II

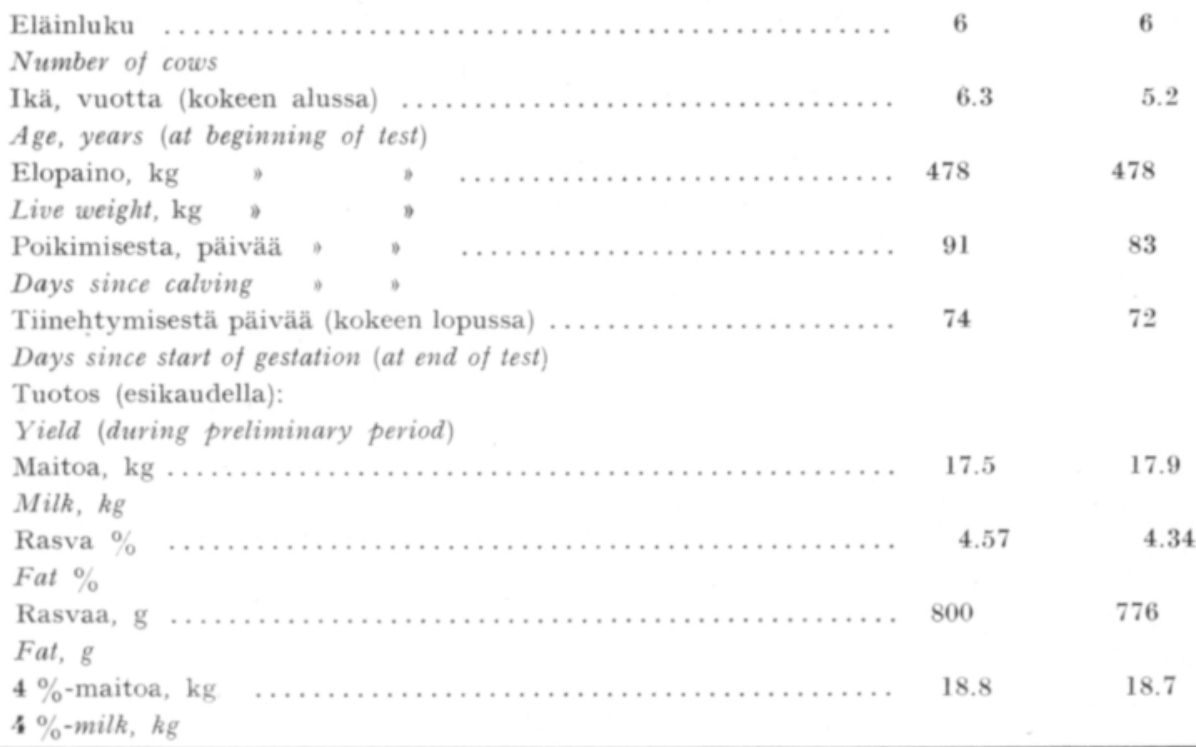

(keskimäärin $2.9 \mathrm{~kg}$ ) eläintä kohti, riippuen lehmän tuotantotasosta, ja hernemäärät vastaavasti $2.1-4.0 \mathrm{~kg}$ (keskimäärin $3.0 \mathrm{~kg}$ ). Määrät olivat siis huomattavasti suurempia kuin HANssovin (5) ruokintakokeissa käyttämät. Virnan ja herneen keskimääräinen prosenttinen osuus väkirehuista ja kokonaisrehumääristä käy ilmi taulukosta 4. Virnaa siis oli n. puolet koko väkirehujen ry-määrästä ja hernettä n. $54 \%$. Väkirehujen sulavan raakavalkuaisen määrästä oli virnan valkuaista $59 \%$ ja herneen $55 \%$. Kaikkien rehujen ry-määrästä oli n. neljännes hernettä tai virnaa ja niiden sulavaraakavalkuaismääristä virnan valkuaista $43 \%$ ja herneen $41 \%$. Kunkin yksityisen lehmän kohdalla olivat pitoisuudet suunnilleen samat, koska kokeessa oli pyritty pitämään herneen ja virnan suhteellinen osuus kaikilla samana. Vaikka herneen ja virnan osuus väkirehuissa oli näin suuri, ja vaikka ne eivät olleet aikaisemmin niitä koskaan saaneet, söivät lehmät niitä hyvin mielellään.

Mitään vakavampia sairaustapauksia ei kokeen aikana esiintynyt. Ainoastaan 1 puhaltumistapaus oli virnaryhmässä koejakson alkupäivinä lehmällä, joka sai $3.6 \mathrm{~kg} / \mathrm{p}$ virnajauhoja ja yht. 7.2 väkirehuja. Puhaltuminen meni nopeasti ohi, kun oli annettu $200 \mathrm{ml}$ Bovinolia. Niinikään oli herneryhmässä 1 ripulitapaus lehmällä, joka sai $4.0 \mathrm{~kg} / \mathrm{p}$ hernettä ja väkirehuja yhteensä $9.4 \mathrm{~kg} / \mathrm{p}$. Ripuli meni kuitenkin nopeasti ohi. Esikaudellakin, jolloin hernettä ja virnaa ei syötetty, oli yksi ripulitapaus ryhmässä II. Ilmeisesti ei herne- ja virnajauhoja syötettäessä aina 
Table 2. Mean chemical composition and calculated nutrition value of the fodder.

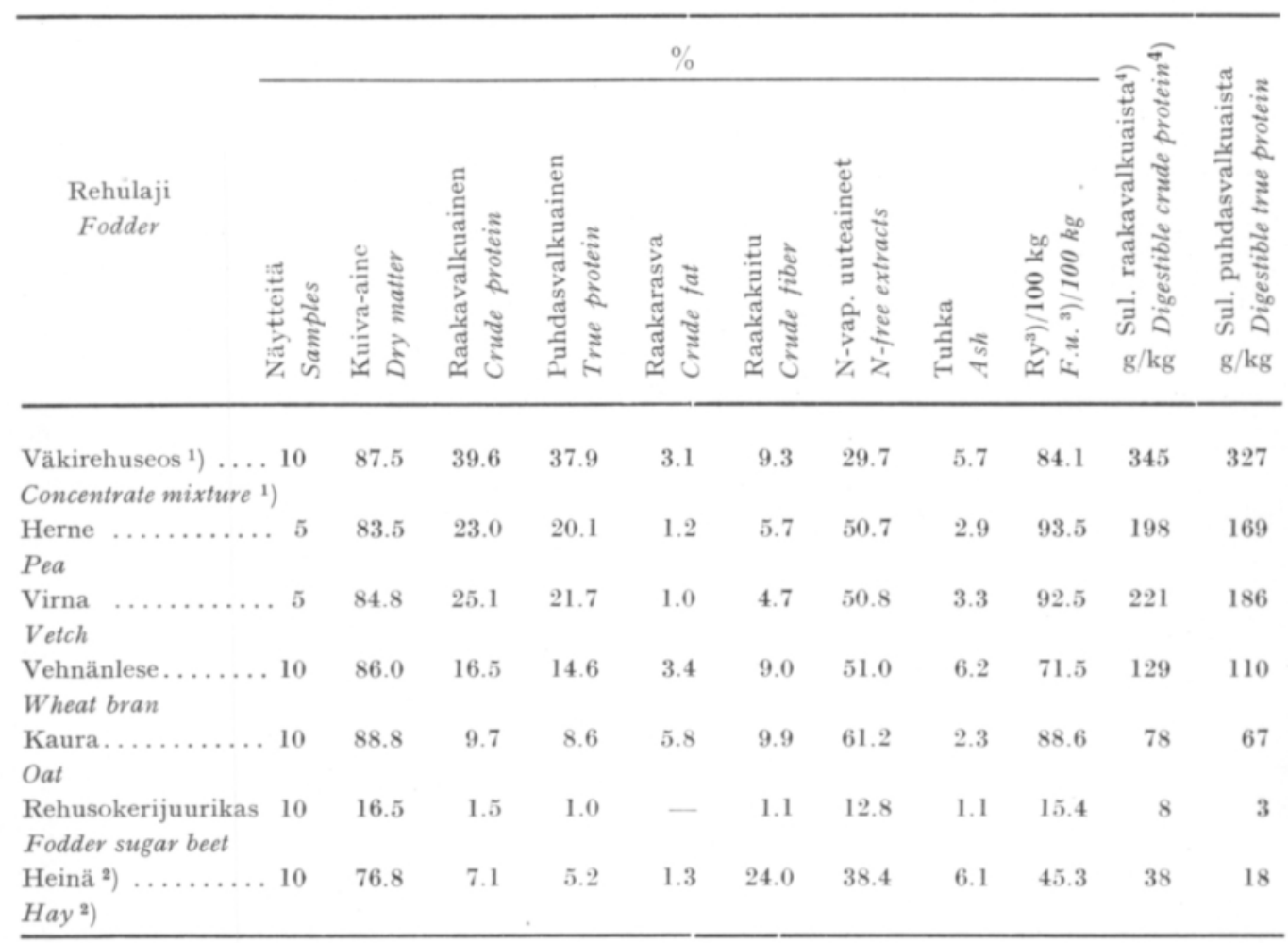

1) $35 \%$ soijarouhetta, $20 \%$ pellavajauhoa, $20 \%$ rypsirouhetta, $15 \%$ maapähkinäjauhoa, $10 \%$ aurinkokukkarouhetta (uutettuja).

$35 \%$ soybean meal, $20 \%$ linseed meal, $20 \%$ rapeseed meal, $15 \%$ peanut meal, $10 \%$ sunflower seed meal, (extracted)

) Timotei, nurminata, puna-apila (vähän) Timothy, meadow fescue, redclover (small quantity)

$\left.{ }^{3}\right) \mathrm{Ry}=0.7$ tärkkelysyksikköä (Kellnerin) F.U. corresponds to 0.7 starch units (Kellner's)

4) Sulavuuskertoimina on käytetty Ruotsin kotieläintutkimuslaitoksen julkaisemia lukuja (8). Figures published by the Swedish Research Institute of Animal Husbandry have been used as the degistion coefficients $(8)$.

$4 \mathrm{~kg} / \mathrm{p}$ asti näytä olevan mainittavaa puhaltumisen tai muun ruuansulatushöiriön vaaraa, edellyttäen, että herne- ja virnajauhojen syöttö alkaa vähitellen päiväannoksia lisäten (kokeessa siirtokausi 5 päivää).

Lehmien keskimääräinen maitotuotos on esitetty taulukossa 5. Koekauden laskettu tuotos on saatu laskemalla esikauden ja jälkikauden keskiarvo. Voidaan todeta, että virnaa ja hernettä sisältävän koekauden ruokinnan aikana on maitomäärä ollut hieman pienempi kuin laskettu määrä olisi edellyttänyt. Sensijaan on $4 \%$-maitomäärä virnaryhmällä ellut käytännöllisesti katsoen lasketun mukainen ja herneryhmällä sitä hieman suurempi, mikä johtuu kummankin ryhmän maidon 
Taulukko 3. Koelehmien syömät keskimääräiset rehumäärät $(\mathrm{kg} / \mathrm{p})$.

Table 3. The average fodder quantities consumed by the test cows (kg per day).

Ryhmä I
Group I
(Virna)
(Vetch)
kg

Ryhmä II

Group II

$(\mathrm{Pea})$

(Herne)

kg

Virna- tai hernejauho

$\left.(2.94)^{2}\right)$

$\left.(3.02)^{2}\right)$

Vetch or pea meal

Väkirehuseos

$1.67^{1}$ )

$\left.(0.53)^{2}\right)$

$\left.1.71^{1}\right)$

$\left.(0.73)^{2}\right)$

Concentrate mixture

Vehnänlese

$1.02^{1}$ )

$\left.(1.40)^{2}\right)$

$0.89^{1}$ )

$\left.(1.01)^{2}\right)$

Wheat bran

Kaurajauho

$\left.3.26^{1}\right)$

$\left.(1.30)^{2}\right)$

$3.37^{1}$ )

$\left.(1.15)^{2}\right)$

Oat meal

Rehusokerijuurikas .

18.98

18.88

Fodder sugar beet

Heinä

6.65

6.50

Hay

Rehusuolaseos ${ }^{3}$ )

0.15

0.13

Fodder salt mixture ${ }^{3}$ )

Sisältäen:

Containing :

Kuiva-ainetta

Dry matter

Ry

F.u.

Sulavaa raakavalkuaista

Digestible crude protein
$\left.{ }^{1}\right)$ esikausi, jälkikausi preliminary period, subsequent period
$\left.{ }^{2}\right)$ koekausi trial period
3) $8.5 \% \mathrm{P}, 27.0 \% \mathrm{Ca}, 4.0 \% \mathrm{NaCl}+\mathrm{Cu}+\mathrm{Co}+\mathrm{J}$

rasvapitoisuuden selvästä kohoamisesti koekaudella. Esikauden ja koekauden 4 \%maitomäärien erotus oli ryhmällä I $-1.16 \mathrm{~kg}$ ja ryhmällä II $-0.89 \mathrm{~kg}$, kun taas rasvapitoisuuksien erotus oli ryhmällä $\mathrm{I}+0.20$ prosenttiyksikköä ja ryhmällä II +0.34 yksikköä. Kokeessa ei voitu todeta herneen tai virnan antavan maidolle normaalista poikkeavaa makua tai hajua (vrt. 13, 10).

Lehmien keskimääräiset elopainot on esitetty taulukossa 6. Elopaino lisääntyi keskimäärin esikaudella ryhmässä I $2 \mathrm{~kg}$ ja ryhmässä II $5 \mathrm{~kg}$, koekaudella kummassakin ryhmässä $11 \mathrm{~kg}$ ja jälkikaudella $18 \mathrm{~kg}$. Elopainon lisääntyminen johtuu siitä, että ruokintaa ei voida aivan tarkoin pitää kokeen kuluessa alenevaa maidon- 
Taulukko 4. Virnan ja herneen määrä rehujen määrästä.

Table 4. Vetch and pea quantities in ratio to the total fodder quantities.

\begin{tabular}{|c|c|c|c|c|}
\hline & $\mathrm{kg}$ & $\begin{array}{l}\text { ry. } \\
\text { F.u. }\end{array}$ & $\begin{array}{c}\text { Sulavaraaka- } \\
\text { valkuainen } \\
\text { Digestible } \\
\text { crude protein }\end{array}$ & $\begin{array}{c}\text { Kuiva- } \\
\text { aine } \\
\text { Dry } \\
\text { matter }\end{array}$ \\
\hline $\begin{array}{l}\text { Virnaa } \% \text { väkirehuista } \ldots \ldots \ldots \ldots \ldots \ldots \\
\text { Vetch, per cent of all concentrates }\end{array}$ & 47.7 & 50.8 & 58.5 & 46.8 \\
\hline $\begin{array}{l}\text { Virnaa } \% \text { rehuista } \ldots \ldots \ldots \ldots \ldots \ldots \ldots \\
\text { Vetch, per cent of all fodder }\end{array}$ & - & 24.1 & 42.7 & 18.5 \\
\hline $\begin{array}{l}\text { Hernettä } \% \text { väkirehuista } \ldots \ldots \ldots \ldots \ldots \\
P e a, \text { per cent of all concentrates }\end{array}$ & 57.9 & 53.7 & 55.4 & 49.8 \\
\hline $\begin{array}{l}\text { Hernettä } \% \text { rehuista } \ldots \ldots \ldots \ldots \ldots \ldots \ldots \\
P e a, \text { per cent of all fodder }\end{array}$ & - & 25.6 & 40.8 & 19.3 \\
\hline
\end{tabular}

Taulukko 5. Lehmien maitotuotos.

Table 5. Milk yield of the cows.

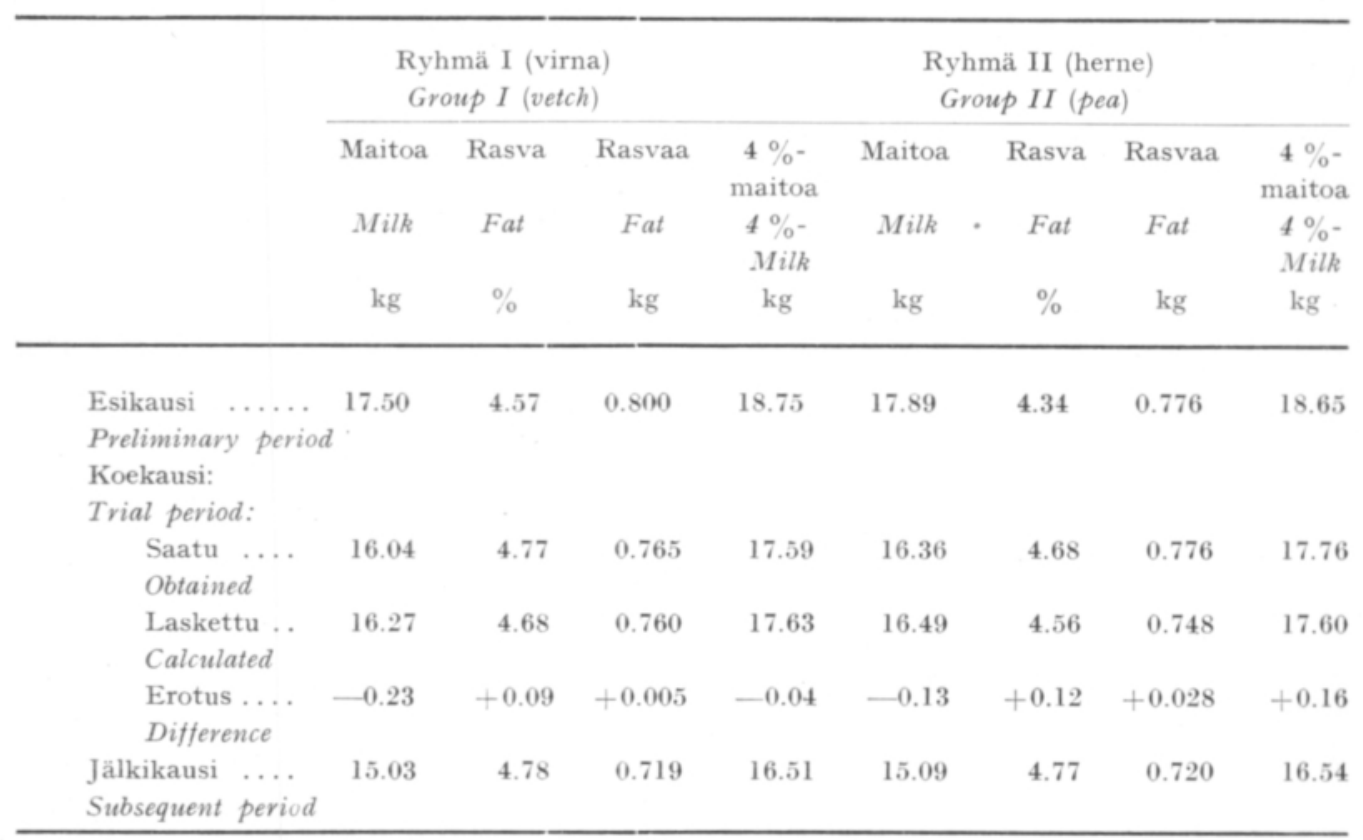

tuotantoa vastaavana, vaan ruokinta oli keskimäärin kokeen aikana 0.5 ry tarvetta suurempi. Koekauden elopainojen lisäys vastaa jokseenkin esikauden ja jälkikauden elopainojen lisäyksen keskiarvoja. 
Taulukko 6. Lehmien keskimääräiset elopainot.

Table 6. Mean live weights of the cows.

$\begin{array}{cc}\text { Ryhmä I } & \text { Ryhmä II } \\ \text { Group I } & \text { Group II } \\ \text { kg } & \mathrm{kg}\end{array}$

Esikausi - Preliminary period $\ldots \ldots \ldots \ldots \ldots \ldots$

Koekausi - Trial period $\ldots \ldots \ldots \ldots \ldots \ldots \ldots \ldots$

Jälkikausi - Subsecuent period $\ldots \ldots \ldots \ldots \ldots \ldots \ldots$

478

480

491

509
478

483

494

512

Taulukko 7. Sulavuuskokeessa käytettyjen rehujen kemiallinen koostumus (\%).

Table 7. Chemical composition of fodder employed in the digestion test, per cent.

\begin{tabular}{|c|c|c|c|c|c|c|c|}
\hline $\begin{array}{c}\text { Rehulaji } \\
\text { Fodder }\end{array}$ & $\begin{array}{l}\text { Kuiva- } \\
\text { aine } \\
\text { Dry } \\
\text { matter }\end{array}$ & $\begin{array}{c}\text { Raaka- } \\
\text { valkuainen } \\
\text { Crude } \\
\text { protein }\end{array}$ & $\begin{array}{c}\text { Puhdas- } \\
\text { valkuainen } \\
\text { True } \\
\text { protein }\end{array}$ & $\begin{array}{c}\text { Raaka- } \\
\text { rasva } \\
\text { Crude } \\
\text { fat }\end{array}$ & $\begin{array}{c}\text { Raaka- } \\
\text { kuitu } \\
\text { Crude } \\
\text { fiber }\end{array}$ & $\begin{array}{c}\text { N-vap. } \\
\text { unteaineit. } \\
\text { N-free } \\
\text { extracts }\end{array}$ & $\begin{array}{c}\text { Tuhka } \\
\text { Ash }\end{array}$ \\
\hline $\begin{array}{l}\text { Heinä } \\
\text { Hay }\end{array}$ & $\ldots \quad 89.4$ & 8.0 & 6.3 & 1.6 & 28.5 & 44.6 & 6.7 \\
\hline $\begin{array}{l}\text { Virna } \\
\text { Vetch }\end{array}$ & $\ldots \quad 90.8$ & 25.1 & 22.0 & 2.0 & 5.4 & 54.0 & 4.3 \\
\hline $\begin{array}{l}\text { Herne } \\
P e a\end{array}$ & $\ldots 90.5$ & 24.2 & 20.9 & 1.8 & 6.9 & 54.2 & 3.4 \\
\hline
\end{tabular}

Taulukko 8. Sulavuuskokeessa saadut sulavuuskertoimet virnalle ja herneelle.

Table 8. Digestion coefficients for vetch and pea, obtained in the digestion test.

\begin{tabular}{|c|c|c|c|c|c|}
\hline $\begin{array}{l}\text { Rehulaji } \\
\text { Fodder }\end{array}$ & $\begin{array}{l}\text { Org. } \\
\text { aine } \\
\text { Organic } \\
\text { matter }\end{array}$ & $\begin{array}{c}\text { Raaka- } \\
\text { valkuainen } \\
\text { Crude } \\
\text { protein }\end{array}$ & $\begin{array}{l}\text { Raaka- } \\
\text { rasva } \\
\text { Crude } \\
\text { fat }\end{array}$ & $\begin{array}{c}\text { Raaka- } \\
\text { kuitu } \\
\text { Crude } \\
\text { fiber }\end{array}$ & $\begin{array}{c}\text { N-vap. } \\
\text { uuteaineet } \\
N \text {-free } \\
\text { extracts }\end{array}$ \\
\hline $\begin{array}{l}\text { Virna } \ldots \ldots \ldots \ldots \ldots \cdots \\
\text { Vetch }\end{array}$ & 90.7 & 88.5 & 84.3 & 62.7 & 94.7 \\
\hline $\begin{array}{l}\text { Poikkeama keskiarvosta } \\
\text { Deviation from mean }\end{array}$ & \pm 1.5 & \pm 0.2 & \pm 0.0 & \pm 14.8 & \pm 0.7 \\
\hline $\begin{array}{l}\text { Herne } \ldots \ldots \ldots \ldots \\
\text { Pea }\end{array}$ & 90.6 & 87.6 & 62.5 & 70.8 & 95.4 \\
\hline $\begin{array}{l}\text { Poikkeama keskiarvosta } \\
\text { Deviation from mean }\end{array}$ & \pm 2.9 & \pm 1.1 & \pm 1.6 & \pm 18.1 & \pm 1.9 \\
\hline
\end{tabular}




\section{Sulavuuskokeet}

Sulavuuskokeet suoritettiin samoilla kahdella pässillä (elopainot $54 \mathrm{~kg}$ ja $46 \mathrm{~kg}$ ) sekä virnalla että herneellä. Perusrehuna oli timoteivaltainen heinä, jota eläimet saivat molemmissa kokeissa $450 \mathrm{~g} / \mathrm{p}$ eläintä kohti, ja jonka sulavuus oli ennen kokeita määritetty. Hernettä ja virnaa ne saivat kumpaakin $350 \mathrm{~g} / \mathrm{p}$ eläintä kohti.

Taulukossa 7 on esitetty sulavuuskokeessa käytettyjen rehujen kemiallinen koostumus. Kokeessa saatiin virnalle ja herneelle taulukossa 8 esitetyt sulavuuskertoimet. Sulavuuskokeissa sulattivat kaksi koe-eläintä hyvin samalla tavalla muut aineosat paitsi raakakuidun. Tämä johtui ilmeisesti siitä, että tutkittavissa rehuissa virnassa ja herneessä on kuitupitoisuus pieni, kun taas perusrehuna käytetyssä heinässä on kuitupitoisuus suuri. Näin ollen, jos perusrehu ei ole täysin tasalaatuista tuntuu vaihtelu herkimmin kuidun sulavuuskertoimissa. Nähdäkseni voitaisiin ko. epäkohta välttää tai ainakin sitä pienentää, ryhtymällä käyttämään sulavuuskokeissa puhdasta timoteita perusrehuna. Puna-apilan kemiallinen koostumus poikkeaa siksi paljon timotein koostumuksesta, että pienikin epätasaisuus aiheuttaa jo merkittävän virheen. Kokeessa saatuja sulavuuskertoimia verrattaessa ruotsalaisessa rehutaulukossa (8) ilmoitettuihin kertoimiin voidaan todeta, että kertoimet ovat virnalla korkeammat muiden aineosien kohdalla paitsi raakavalkuaisen, joka on samaa tasoa. Herneelle saadut sulavuuskertoimet ovat saman suuntaiset kuin virnallakin, paitsi että raakarasvan sulavuuskerroin on hieman pienempi. Raakakuidun sulavuus on ollut jokaisessa tapauksessa suurempi, rinnakkaiskokeetkin erikseen huomioiden. Typpitase oli molemmissa kokeissa positiivinen, $+1.5 \mathrm{~g}$ herneellä ja $+2.6 \mathrm{~g}$ virnalla.

\section{Tulosten tarkastelua}

Kokeen perusteella voidaan todeta, että virna ja herne sopivat hyvin lypsylehmille rehuksi. Kokeessa käytetyissä virnoissa (84.8 \% kuiva-ainetta) oli $22.1 \%$ sulavaa raakavalkuaista ja 1 rehuyksikköä vastasi $1.08 \mathrm{~kg}$, ja herneissä $19.8 \%$ (83.5 \% kuiva-ainetta) sulavaa raakavalkuaista ja 1 rehuyksikköä vastasi $1.07 \mathrm{~kg}$. (Rehuyksikkö $=0.7$ tärkkelysyksikköä). Skandinaavisen ry-järjestelmän (HANssoNin mukaan laskettuna vastaisi 1 ry:ä näillä rehuilla $1.02 \mathrm{~kg}$. Lehmät söivät erittäin mielellään väkirehuseoksessa virnaa ja hernettä, joiden määrät olivat kokeessa $2.2-3.7 \mathrm{~kg} / \mathrm{p}$ eläintä kohti virnaa ja $2.1-4.0 \mathrm{~kg} / \mathrm{p}$ hernettä, riippuen lehmien tuotantotasosta. Eläinten saamista kokonaisrehuyksikkömääristä oli virnaa tai hernettä n. $25 \%$ ja sulavaraakavalkuaismääristä virnaa $43 \%$ ja hernettä $41 \%$. Väkirehujen ry-määristä oli n. $51 \%$ virnaa ja n. $54 \%$ hernettä ja sulavaraakavalkuaismääristä virnan valkuaista $59 \%$ ja herneen $55 \%$. Alkuperäisenä tarkoituksena oli jättää öljyväkirehut kokonaan pois koekaudella, mutta kokeissa käytetyt heinä ja kaurajauho osoittautuivat normaalia valkuaisköyhemmiksi, jonka vuoksi käytettiin pieniä öljyväkirehumääriä (keskim. virnaryhmässä $0.53 \mathrm{~kg}$ ja herneryhmässä $0.73 \mathrm{~kg}$ ). Öljyväkirehujen jättäminen kokonaan pois olisi tässä tapauksessa johtanut siihen, että alempiprosenttisten väkirehujen kauran ja vehnänleseen määrät 
olisivat myös tulleet pieniksi, ja väkirehut olisivat sisältäneet suurimmaksi osaksi virnaa tai hernettä. Käytännössä ei useimmissa tapauksissa tuottane vaikeutta käytettäessä virnaa ja hernettä saada ilman öljyväkirehuja rehuannoksen valkuaispitoisuutta riittäväksi runsastuottoisillekin lehmille, jos heinien ja kaurajauhojen valkuaispitoisuus ovat normaalia tasoa. Erityisen helposti saadaan valkuaismäärät riittäviksi siinä tapauksessa, että on käytettävissä nuoresta heinästä, odelmasta ym. tehtyä säilörehua. HANSson (5) katsoo, että ainakin $50 \%$ öljyväkirehujen valkuaisesta voidaan korvata herneellä tai virnalla. Suorittamassani ruokintakokeessa korvattiin $60-70 \%$, ja nähdäkseni ei ole mitään estettä kokonaankin korvata öljyväkirehut virnalla tai herneellä, jos rehuannokseen kokonaisuudessaan saadaan riittävä valkuaismäärä käyttämällä enintään n. puolet alhaisprosenttisia väkirehuja ja puolet virnaa tai hernettä. Monessa tapauksessa päästään riittävään valkuaismäärään edellistä pienemmilläkin virna- tai hernemäärillä.

Herneen (ja virnan) valkuaisen aminohappokoostumuksesta on mainittava, että se tavallisimmista väkirehuista lähinnä muistuttaa soijan valkuaisen koostumusta. Esimerkiksi on mainittava, että valkuaisen lysiinipitoisyus on korkea kuten soijassakin, kun taas viljakasvien lysiinipitoisuus on alhaisempi. Maito on juuri erityisen lysiinipitoista (2). On kuitenkin muistettava, että märehtijöillä ei rehujen valkuaisen määrätty aminohappokoostunus ole yhtä tärkeä kuin yksimahaisilla, koska pötsin pieneliöstö voi syntetisoida niitä (määrätyissä rajoissa) yksinkertaisemmista typpiyhdistyksistä (3). On esitetty, etteivät monipuoliset väkirehuseokset ole lehmien ruokinnassa parempia kuin yksi väkirehu (esim. 4). (Vrt. 12.) Sulavuuskokeitten tulokset osoittavat, että herneen ja virnan sulavuudet ovat parhaimpien väkirehujen veroisia.

\section{Yhteenveto}

Herneiden ja virnojen ravintoarvon selvittämiseksi on suoritettu maidontuotantokoe lehmillä sekä sulavuuskokeet pässeillä.

Maidontuotantokokeessa käytetyissä virnajauhoissa (84.8\% kuiva-ainetta) oli $22.1 \%$ sulavaa raakavalkuaista ja 1 ry:ä vastasi $1.08 \mathrm{~kg}$, ja hernejauhossa $(83.5 \%$ kuiva-ainetta) $19.8 \%$ sulavaa raakavalkuaista ja 1 ry:ä vastasi $1.07 \mathrm{~kg}$ (ry $=0.7$ tärkkelysyksikköä). Skandinaavisen ry-järjestelmän (HANssovin) mukaan laskettuna vastasi 1 ry:ä näillä rehuilla $1.02 \mathrm{~kg}$.

Maidontuotantokokeessa käytettiin virnaa $2.2-3.7 \mathrm{~kg}$ (keskim. $2.9 \mathrm{~kg}$ ) ja hernettä $2.1-4.0$ (keskim. $3.0 \mathrm{~kg}$ ) $/ \mathrm{p}$ eläintä kohti, eläinten tuotostasosta riippuen. Virnaa oli n. puolet ja hernettä hieman yli puolet koko väkirehujen ry-määrästä. Väkirehujen sulavan raakavalkuaisen määrästä oli virnan valkuaista $59 \%$ ja herneen $55 \%$. Kaikkien rehujen ry-määrästä oli n. neljännes hernettä tai virnaa ja niiden sulavaraakavalkuaismääristä virnan valkuaista $43 \%$ ja herneen $41 \%$.

Lehmät söivät herne- ja virnajauhoa sisältävää väkirehuseosta mielellään. Kokeen aikana sattui 1 lievä puhaltumistapaus virnaryhmässä toiseksi eniten $(3.6 \mathrm{~kg} / \mathrm{p})$ sitä saaneella lehmällä. Ruuansulatushäiriöitten vaara ei ole suuri ainakaan siinä tapauksessa, jos herne- ja virnajauhojen syöttö aloitetaan pienillä määrillä päiväannoksia vähitellen (5 p:nä) lisäten. 
Virnaa tai hernettä sisältävän koekauden $4 \%$ - maidon määrä ei ole vähentynyt. Sensijaan maidon kokonaismäärä on vähentynyt, mutta rasvapitoisuus on kohonnut, mikä juuri aiheuttaa, että $4 \%$ - maidon määrä ei ole vähentynyt. Normaalista poikkeavaa makua tai hajua ei voitu kokeen aikana havaita olevan maidossa. Koekauden elopainojen lisäys vastaa esikauden ja jälkikauden elopainojen lisäyksen keskiarvoa.

Kokeissa käytetyt virna- ja hernemäärät olivat siksi suuria (keskim. n. puolet väkirehumääristä), että käytännössä sellaisilla määrillä (ja pienemmilläkin) päästään riittäviin valkuaismääriin, jos muiden kotoisten rehujen valkuaispitoisuus on normaalia tasoa vastaava.

Sulavuuskokeiden tulokset osoittivat, että herne- ja virnajauhon sulavuus on sellainen, että ne voidaan lukea siinä suhteessa parhaimpien väkirehujen joukkoon.

Herneen ja virnan viljeleminen puhdaskasvustoina on lakoutumisen vuoksi epävarmempaa kuin sekakasvustoina. Viljelyn epävarmuus ilmeisesti on aiheuttanut sen, että kauppavaatimukset täyttävän herneen ja virnan nykyinen hinta on siksi korkea, että sellaisen tavaran käyttöä lypsylehmien rehuksi ei voida ajatella. Seosviljelyssä (tavallisesti kauran kanssa) lakoutumisen vaara on pienempi, ja herne- ja virna tuleentuvat niissä aikaisemmin, joten niitä voidaan viljellä nykyistä pohjoisempana. Pyrittäessä kohottamaan kotovaraisten rehusatojen valkuaispitoisuutta on syytä kiinnittää huomiota virnan ja herneen seosviljelyyn, koska ne sisältävät runsaasti valkuaista ja ovat lypsykarjan ruokintaan hyvin soveltuvia rehuja.

\section{KIRJALLISUUTTA}

(1) Anttinen, O. 1948. Hernekauran viljelysmahdollisuuksista Pohjois-Pohjanmaalla. Koetoim. ja käyt. $5: 31-32$.

(2) Block, R. J. \& Bolling, D. 1951. The amino acid composition of proteins and foods. $576 \mathrm{~s}$. Illinois.

(3) Brody, S. 1945. Bioenergetics and growth. 1023 s. New York.

(4) Dawson, J. R. \& Watt, A. L. \& Mc Intyre, C. W. \& Leighton, R. E. \& Graves, R. R. 1944. Single grains and grain mixtures as supplements to alfalfa hay and silage for milk poduction. Unit. Stat. Dep. of Agric. Circ. 696:

(5) Haxsson, N. 1912. Baljvaxtgröpets fodervärde vid mjölkproduktion. Centralanst. medd. 66: $1-28$.

(6) —- 1913. Handbok i utfodringslära. 460 s. Stockholm.

(7) HüNninen, P. 1956. Herneen ja virnan viljelysmahdollisuuksista kaurakasvustossa Suomessa. (English summary) Erip., $131 \mathrm{~s}$.

(8) K. Lantbrukshögskolan och Statens Lantbruksförsök, Statens Husdjursförsök 1951. Foder medlens sammansättning, smältbarhet och näringsvärde. $29 \mathrm{~s}$. Stockholm.

(9) Koskinen, Y. K. 1948. Eräitä koetuloksia ja kokemuksia rehupalkokasvien viljelystä EteläSavon koeasemalla. Koetoim. ja käyt. 5: 40.

(10) NoRdFelt, S. 1957. Smältbarhetsförsök och utfodringsförsök med åkerböna (Vicia faba minor). K. lantbr. högsk. medd. 123. Erip., $12 \mathrm{~s}$.

(11) PoIJÄRvI, I. 1925. Suomalaisen lypsykarjan ravinnontarve käytännöllisten ruokintakokeiden valossa. Maatal.koel. tiet. julk. 26: 1-137. 
PoIJÄRvi, I. 1958. Eräiden syčttötapojen vaikutuksesta väkirehujen ravintotehoon märehtijäin ruokinnassa. Valt. maatal. koetoim. tiedonant. 238: 1-20.

(13) Rosengren, L. Fr. 1912. Baljväxtfröns inverkan på smörets beskaffenhet. Centralanst. medd. 70: $1-6$.

(14) VAlle, O. 1946. Palkokasvien merkitys rehuviljan tuotannossa. Maatal. ja koetoim. 1. Erip. $20 \mathrm{~s}$.

(15) VIRRI, T. J. 1951. Herne-kauran viljelystä. (Deutsch. Ref.) Maatal.tiet. aikak. 23: 222—230.

S U M M A R Y :

PEA AND VETCH AS FODDER FOR MILK COWS

IRJA UOTILA

Agricultural Research Centre, Department of Animal Husbandry, Tikkurila.

The investigation concerns trials with pea and vetch (finely ground), performed as a milk yield test with cows and as digestion tests with wethers,

The vetch meal $(\mathbf{8 4 . 8} \%$ dry matter) used in the milk yield test contained $22.1 \%$ digestible crude protein, the quantity equivalent to one food unit was $1.08 \mathrm{~kg}$. The pea meal $(83.5 \%$ dry matter $)$ contained $19.8 \%$ digestible crude protein, $1.07 \mathrm{~kg}$ of the meal corresponding to one food unit. (1 F.U. $=0.7$ Kellner's starch units) (Table 2, p. 22.) Calculated according to the Scandinavian food unit system (Hansson), $1.02 \mathrm{~kg}$ of either fodder would be equivalent to one food unit.

In the milk yield test the quantity of vetch used was 2.2 to $3.7 \mathrm{~kg}$ (average $2.9 \mathrm{~kg}$ ) and the quantity of peas 2.1 to $4.0 \mathrm{~kg}$ (average $3.0 \mathrm{~kg}$ ) per animal and day, depending on the yield level of the animal. About half of the total F.U. quantity of the concentrates was made up of vetch, while pea accounted for somewhat over one half. The total digestible crude protein in the concentrates consisted, respectively, of $59 \%$ protein from the vetch and $55 \%$ protein from peas. About one quarter of the total food unit quantity of all fodder consisted of peas or vetch, $43 \%$ and $41 \%$ of their digestible crude protein quantities being made up of vetch or pea proteins respectively (Tables 3 and 4, p. $23-24$ ).

The concentrate mixture containing pea and vetch meal was readily eaten by the cows. One mild case of bloat occurred in the vetch group, the animal concerned being the cow which had received the second largest amount of vetch meal $(3.6 \mathrm{~kg}$ per day). The risk of digestive disturbances is not great, particularly if the administration of pea and vetch meal is commenced with small quantities daily gradually increasing the rations (during a period of five days).

The quantity of $4 \%$ milk obtained during the trial period of the pea or vetch administration did not decrease. On the other hand the total milk quantity was less. Its fat content was however higher in that way resulting in an unchanged $4 \%$ milk yield (Table 5, p. 24). No taste or small different from normal could be observed in the milk during the test. The increases in live weight during the trial period were equivalent to the means of the corresponding figures for the preliminary and subsequent periods (Table 6, p. 25).

The vetch and pea quantities employed in the trials were of a size (on an average about one half of the concentrate quantities) that would ensure an adequate protein supply in practice with such amounts (and even with smaller ones) providing the protein content of the other domestic fodder substances is kept normal.

The digestion trials were carried out with wethers, the test being performed with two animals for each experimental fodder. The basic ration consisted of $450 \mathrm{~g}$ timothy-dominated hay per day while $350 \mathrm{~g}$ pea or vetch meal per day were given in addition. The chemical composition of the fodder used in the digestion trials (\%) is shown in Table 7 (p. 25). In the digestion trials all other constituents 
except the crude fiber were digested by the animals in each instance. Such a difference may be caused by even a minor deviation in the homogeneity of the basic fodder, which had a high fiber content in the tests. This might be reduced by employing pure timothy as basic fodder in the digestion trials. The nitrogen balanced was positive, $+1.5 \mathrm{~g}$ with pea meal and $+2.6 \mathrm{~g}$ with vetch meal, respectively. On the whole it appears from the results of the digestion trials that the digestibility of pea and vetch meal is such that these fodder can be considered as ranking among the very best concentrates in this respect.

The cultivation of pure pea and vetch is apt to be less successful in Finland than their mixed cultivation (usually with oats) owing to the tendency of the plants to lodge. Moreover, pea and vetch ripen earlier in mixtures so that they can in fact be grown further north than is the case at present (7). Of the fodder plants cultivated in this country vetch and pea have the highest protein content. In attempting to increase the protein content of our domestic fodder crops attention should be paid to the mixed cultivation of vetches and peas since they are rich in protein and are fodder of a kind well suited for the feeding of milk cattle. 